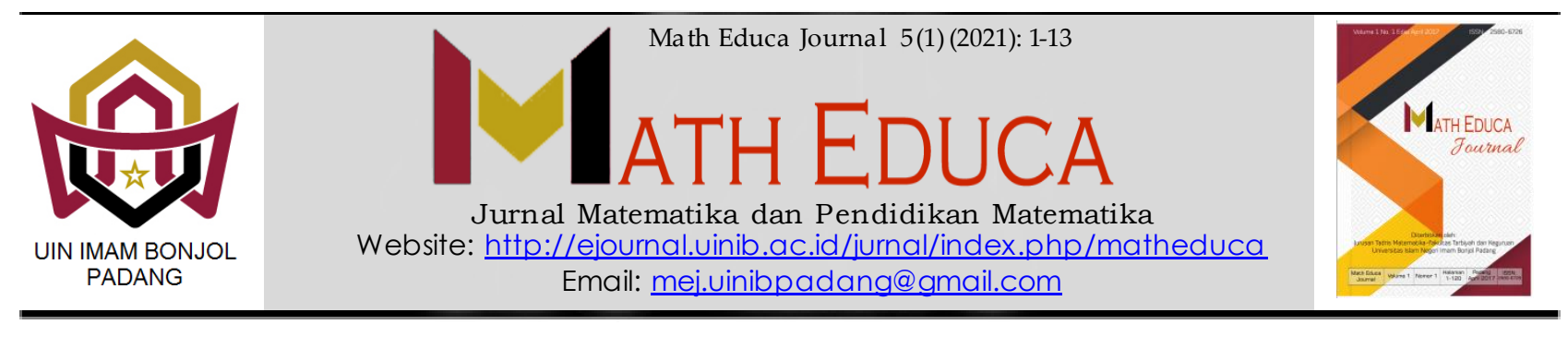

\title{
PENGEMBANGAN MEDIA BELAJAR BARET ARGEO BERBASIS ROLE PLAYING GAME TERHADAP MINAT BELAJAR SISWA
}

\author{
'Muhammad Ikhsan Faiz*, ${ }^{2}$ Teguh Wibowo, ${ }^{3}$ Bambang Priyo Darminto \\ 1,2,3 Universitas Muhammadiyah Purworejo \\ E-mail: 1muhammadikhsansenpai@gmail.com,2teguhwibowo743@gmail.com, \\ 3bambangpdc115@gmail.com
}

Received: February 2021; Accepted: March 2021; Published: April 2021

\begin{abstract}
This research aims to establish a valid, practical, and effective media in the form of a game called Baret Argeo for students interest in learning at Senior High School 6 of Purworejo during online learning. This research is a development study that employs the ADDIE method (analysis, design, development, implementation, evaluation). A required analysis is carried out according to pandemic conditions during the analysis stage. The Baret Argeo design and components were produced during the design stage. Validation was carried out by content experts with a value of 3.93 (valid) and media experts with a value of 4.46 at the production level (very valid). which was then put to the test on 18 students in a practicality test with a score of 4.03 (very practical). Then the implementation of the 18 students used the Argeo Beret which was compared with the other 18 students who used the Student Worksheet (LKS) using the $t$ test comparative analysis. The result is $t_{\text {count }}>t_{\text {table }}$ with 4.4881> 2.0322 then $H_{0}$ is rejected or it can be said that students' interest in learning using Beret Argeo is better than students using LKS. At the evaluation stage, the Argeo Beret is reserved to be used in a wider range of mathematics learning. This research has implications for students' interest in learning in the middle of distance learning.
\end{abstract}

Keywords: Learning media, baret argeo, learning interest

\begin{abstract}
Abstrak
Penelitian ini bertujuan mengembangankan media berbentuk game bernama Baret Argeo yang valid, praktis, dan efektif terhadap minat belajar siswa SMA Negeri 6 Purworejo pada saat pembelajaran jarak jauh. Penelitian ini merupakan penelitian pengembangan dengan metode ADDIE (analysis, design, development, implementation, evaluation). Pada tahap analisis dilakukan analisis kebutuhan disesuaikan dengan kondisi pandemi. Pada tahap desain dilakukan pembuatan desain dan komponen Baret Argeo. Pada tahap pengembangan dilakukan validasi oleh ahli materi dengan nilai 3,93 (valid) dan ahli media dengan nilai 4,46 (sangat valid)yang selanjutnya dilakukan uji kepraktisan kepada18 siswa dengan nilai 4,03 (sangat praktis). Kemu dian implementasi kepada 18 siswa menggunakan Baret Argeo yang dibandingkan dengan 18 siswa lainnya yang menggunakan Lembar Kerja Siswa (LKS) dengan menggunakan komparasi analisis uji t. Hasilnya yaitu $t_{\text {hitung }}>t_{\text {tabel }}$ dengan 4,4881 $>2,0322$ maka $H_{0}$ ditolak atau dapat dikatakan minat belajar siswa yang menggunakan Baret Argeo lebih baik daripada siswa menggunakan LKS. Pada
\end{abstract}

\footnotetext{
${ }^{*}$ Corresponding author.

Peer review under responsibility UIN Imam Bonjol Padang.

(C) 2021 UIN Imam Bonjol Padang. All rights reserved.

p-ISSN: 2580-6726

e-ISSN: 2598-2133
} 
tahap evaluasi, Baret Argeo diperbaiki untuk dapat digunakan dalam pembelajaran matematika yang lebih luas lagi. Penelitian ini berimplikasi pada minat belajar siswa di tengah pembelajaran jarak jauh.

Kata kunci: Media belajar, baret argeo, minat belajar

\section{PENDAHULUAN}

Teknologi yang berkembang sangat pesat serba digital atau biasa disebut dengan Society 5.0 juga menuntut masyarakat dalam hal ini pelaku pendidikan (guru dan siswa) untuk dapat mengikuti arus yang serba digital tersebut. Pelaku pendidikan harus mengikuti perkembangan teknologi. Media pembelajaran matematika berbasis teknologi dapat dikembangkan dengan memanfaatkan apa yang siswa inginkan saat ini. Langkah pengembangan media pembelajaran matematika berbasis teknologi ini dilakukan karena siswa yang menggunakan teknologi itu tidak digunakan dengan sebaik-baiknya dalam artian lain siswa menggunakan untuk hal lain seperti bermain game.

Siswa saat ini lebih tertarik dengan game daripada buku pelajaran terlebih lagii saat ini siswa dapat mengakses informasi dengan mudahnya dan memanfaatkan peekembangan internet daripada media konvensional (Suparni \& Handayani, 2018: 1). Oleh karena itu media pembelajaran matematika yang dikembangkan adalah media pembelajaran berbasis game. Selanjutnya, game yang disukai generasi saat ini adalah game yang mempunyai suatu jalan cerita atau game sekelas Role Play Gaming
(RPG). RPG dipilih karena berdasarkan survei yang dilakukan oleh Agate Studio dalam Fuqoha (2015) menghasilkan bahwa RPG adalah game paling populer.

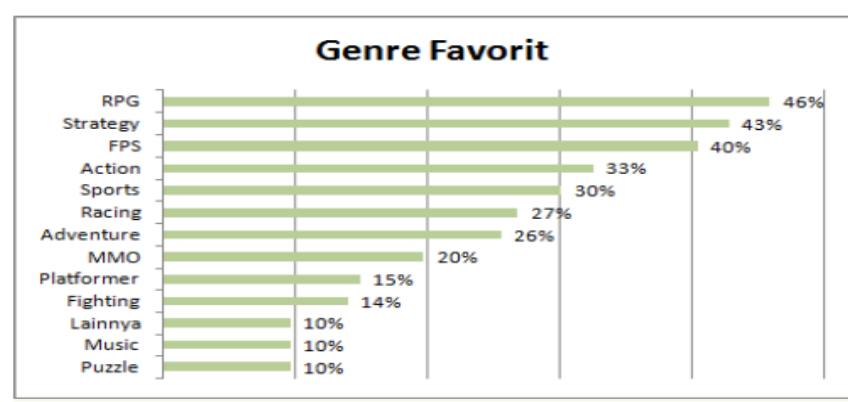

Gambar 1. Survei oleh Agate Studio Jenis Game Populer

Game RPG yang di dalamnya berisi cerita atau dapat dikatakan mempunyai jalan cerita yang dapat dikembangkan oleh guru selaku pembuat game. Media pembelajaran berbasis RPG ini diberi nama "Baret Argeo" atau singkatan dari Barisan Deret Aritmetika dan Geometri.

Pada masa pandemi Corona Virus Desease-19 (COVID-19) yang merubah tatanan pendidikan terutama ruang belajar. Ruang belajar yang dibuat menjadi ruang belajar jarak jauh atau dengan menggunakan teknologi. Munir (2009: 9) menyatakan bahwa pembelajaran jarak jauh adalah pembelajaran yang dirancang yang dilakukan dengan keterbatasan tatap muka atau terpisahnya pendidik dan peserta didik 
dengan memanfaatkan media teknologi informasi karena perbedaan tempat dan waktu. Pengembangan media pembelajaran berbasis game ini juga akan berguna saat pembelajaran jarak jauh karena tanpa adanya pengawasan guru, siswa akan cenderung menurun dari segi minat belajar siswa. Pembelajaran jarak jauh apabila dilakukan dengan tepat, dampak kepada siswa juga akan sama dengan pembelajaran langsung. Perlu adanya media pembelajaran yang interaktif dalam pengaplikasiannya.

Menurut Fadillah (2016: 116) minat belajar adalah suatu kesukaan, kegiatan atau aktivitas yang akan mendukung kelancaran kegiatan belajar. Siagian (2015: 126) berpendapat bahwa minat belajar adalah penerimaan akan suatu hubungan antara diri sendiri dengan sesuatu dari luar dapat berupa orang lain, objek, atau suatu aktivitas lainnya. Jadi minat belajar adalah suatu kesukaan untuk menerima sesuatu dari luar yang menimbulkan rasa ketertarikan terhadap subjek belajar sehingga dapat mendukung kelancaran pembelajaran sehingga bermuara pada kepuasaan terhadap sesuatu yang diminati.

Materi barisan dan deret akan menjadi materi dalam pengembangan media berbasis game ini karena menurut Masjudin (2016: 77) menyatakan bahwa materi barisan dan deret adalah materi dengan tingkat pemahaman yang masih rendah atau kurang bermakna bagi siswa karena dibutuhkan konsep materi yang mudah dipahami serta kewenangan siswa untuk terlibat aktif dalam pembelajaran materi barisan dan deret.

Game yang akan diaplikasikan dalam android dan komputer ini juga diharapkan akan berguna karena pembelajaran pada tahun 2020-2021 yang dilakukan secara daring dan memanfaatkan android dan komputer. Game Baret Argeo ini dirasa cocok terhadap perubahan pendidikan seperti pada masa pandemi tersebut. Karena memang perubahan sistem pendidikan yang bersifat insidental harus disiasati dengan baik agar pendidikan tetap berjalan sebagaimana mestinya.

Jadi game Baret Argeo ini diharapkan membantu siswa dalam pembelajaran jarak jauh terutama pada pembelajaran matematika materi barisan dan deret. Media ini juga diharapkan mampu menumbuhkan minat belajar siswa dalam matematika. Baret Argeo yang dapat diinstall melalui android dan dapat dimainkan kapan saja dan dimana saja.

\section{METODE PENELITIAN}

\section{Jenis Penelitian}

Pada penelitian pengembangan ini, peneliti menggunakan model pengembangan dan penelitian atau biasa disebut dengan Research and Development (R\&D) dengan model pengembangan ADDIE (analysis, 
design, development, implementation, evaluation).

\section{Waktu dan Tempat Penelitian}

Penelitian ini dilaksanakan pada bulan Februari 2021 bertempat di SMA Negeri 6 Purworejo.

Target/Subjek Penelitian/Populasi dan Sampel

Penelitian ini dilakukan kepada satu kelas XI MIPA 1 yang terdiri dari 18 siswa menggunakan Baret Argeo dan sebagai pembanding yaitu 18 siswa menggunakan Lembar Kerja Siswa (LKS).

\section{Prosedur}

Metode pemilihan sampel yaitu dengan metode Cluster Random Sampling. Menurut Nazir (2013: 311) cluster sampling adalah teknik memilih sebuah sampel dari kelompok-kelompok unit yang lebih kecil atau biasa disebut cluster. Unsur-unsur dalam cluster sifatnya tidak homogen atau dapat dikatakan menyerupai populasi sendiri. Sedangkan random adalah pengambilan cluster dilakukan secara random atau acak. Kelas subjek penelitian dipilih secara random dari tiga kelas XI MIPA yaitu kelas XI MIPA 1 SMA Negeri 6 Purworejo.

\section{Data, Intrumen, dan Teknik Pengumpulan Data}

Instrumen penelitian berupa instrumen kualitatif berupa wawancara kepada siswa dan lembar observasi serta data kuantitatif berupa angket validasi media, angket validasi materi, angket uji kepraktisan, angket uji keefektifan terhadap minat belajar siswa.

Data wawancara dikumpulkan sebelum penggunaan media untuk mengetahui kebutuhan siswa. Validasi dilakukan oleh dua ahli media dan dua ahli materi. Uji kepraktisan diisi oleh 18 siswa yang menggunakan Baret Argeo. Angket uji keefektifan diisi oleh siswa yang menggunakan LKS dan Baret Argeo. Sedangkan lembar observasi sebagai data pendukung jalannya penelitian.

\section{Teknik Analisis Data}

1. Data Kualitatif

Data kualitatif yang didapat berupa wawancara dan hasil observasi. Pada teknik analisis kualitatif dengan reduksi data, penyajian data dengan uraian singkat, dan simpulan data.

2. Data Kuantitatif

a. Validasi Produk

Pada validitas produk berdasarkan hasil respon dari ahli media dan ahli materi. Berikut tahapan analisis validasi produk menurut Khabibah dalam Nurtasari \& Manoy (2016: 4):

1) Mencari rata-rata tiap kriteria dari validator dengan rumus:

$$
K_{i}=\frac{\sum_{i=1}^{n} V_{h i}}{n}
$$

2) Mencari rata-rata aspek dengan rumus: 


$$
A_{i}=\frac{\sum_{j=1}^{n} K_{i j}}{m}
$$

3) Mencari rata-rata total validasi dengan rumus:

$$
R T V=\frac{\sum_{i=1}^{n} A_{i}}{n}
$$

4) Menentukan kategori kevalidan dengan mencocokkan rata-rata total dengan kriteria dari skala Likert:

\section{Tabel 1. Tingkat Kevalidan berdasarkan} Skala Likert

\begin{tabular}{cc}
\hline $\begin{array}{c}\text { Interval Rata-rata } \\
\text { Skor }\end{array}$ & $\begin{array}{c}\text { Tingkat } \\
\text { Kevalidan }\end{array}$ \\
\hline $\mathbf{4} \leq \boldsymbol{R} \boldsymbol{T} \boldsymbol{V} \leq \mathbf{5}$ & Sangat Valid \\
\hline $\mathbf{3} \leq \boldsymbol{R} \boldsymbol{T} \boldsymbol{V}<\mathbf{4}$ & Valid \\
\hline $\mathbf{2} \leq \boldsymbol{R} \boldsymbol{T} \boldsymbol{V}<\mathbf{3}$ & Kurang Valid \\
\hline $\mathbf{1} \leq \boldsymbol{R} \boldsymbol{T} \boldsymbol{V}<\mathbf{2}$ & Tidak Valid \\
\hline
\end{tabular}

b. Uji Kepraktisan

Media pembelajaran dikatakan praktis apabila dapat di uji cobakan di lapangan. Berdasarkan Khabibah dalam Nurtasari \& Manoy (2016: 4) berikut tahapan uji kepraktisan produk:

1) Mencari rata-rata tiap kriteria dari respon siswa dengan rumus:

$$
K_{i}=\frac{\sum_{i=1}^{n} P_{h i}}{n}
$$

2) Mencari rata-rata total kepraktisan dengan rumus:

$$
R T P=\frac{\sum_{i=1}^{n} K_{i}}{n}
$$

3) Menentukan kategori kepraktisan dengan kriteria dari skala Likert:
Tabel 2. Tingkat Kepraktisan

\section{berdasarkan Skala Likert}

\begin{tabular}{cc}
\hline $\begin{array}{c}\text { Interval Rata-rata } \\
\text { Skor }\end{array}$ & $\begin{array}{c}\text { Tingkat } \\
\text { Kepraktisan }\end{array}$ \\
\hline $\mathbf{4} \leq \boldsymbol{R T P} \leq \mathbf{5}$ & Sangat Praktis \\
\hline $\mathbf{3} \leq \boldsymbol{R} \boldsymbol{T} \boldsymbol{P}<\mathbf{4}$ & Praktis \\
\hline $\mathbf{2} \leq \boldsymbol{R} \boldsymbol{P}<\mathbf{3}$ & Kurang Praktis \\
\hline $\mathbf{1} \leq \boldsymbol{R} \boldsymbol{T} \boldsymbol{P}<\mathbf{2}$ & Tidak Praktis \\
\hline
\end{tabular}

c. Uji Keefektifan

Keefektifan produk disini berdasarkan respon dari pemain atau siswa yang diteliti. Akan dibandingkan antara angket buku LKS dan angket Baret Argeo. Sebelumnya data akan diubah ke bentuk interval dengan cara:

$$
\text { Data interval }=\frac{\text { Skor siswa }}{\text { Skor } \text { maksimal }} \times 100
$$

Beberapa analisis data yang digunakan sebagai berikut:

1) Uji Normalitas

Dalam penelitian ini uji normalitas yang akan digunakan dengan metode Kolmogorv-Smirnov.

$$
D_{\text {hitung }}=\operatorname{maks}\left|p_{k}-F(Z i)\right| \text {. }
$$

2) Uji Homogenitas

Pada penelitian ini akan digunakan uji homogenitas dengan uji $\mathrm{F}$ karena hanya dua kelas sampel.

$$
F_{\text {hitung }}=\frac{\text { Variansi besar }}{\text { Variansi kecil }}
$$

3) Uji t

Uji $t$ dipilih karena pada uji $t$ digunakan jika sampel jauh dari populasi atau biasanya kurang dari setengah populasi. Uji $t$ yang 
digunakan adalah t-test: two-sample assuming equal variances karena sampel yang digunakan independen atau tidak terkait dan berasal dari variansi yang sama.

$$
t=\frac{\bar{X}_{1}-\bar{X}_{2}}{s p \sqrt{\frac{1}{n_{1}}+\frac{1}{n_{2}}}}
$$

\section{HASIL PENELITIAN DAN PEMBAHASAN}

\section{Analisis}

Media pembelajaran berbasis teknologi ini akan bepengaruh terhadap minat belajar. Setiap siswa mempunyai kecenderungan yang asasi untuk berminat terjadap suatu bidang belajar. Tetapi, keberminatan siswa terhadap suatu bidang belajar yang rendah dapat diperbaiki dengan salah satunya adalah media pembelajaran yang inovatif. Media pembelajaran Baret Argeo diharapkan akan berpengaruh terhadap minat belajar siswa SMA pada bidang matematika terutama materi barisan dan deret. Terlebih lagi pada masa pandemi dengan belajar mandiri, diharapkan Baret Argeo dapat memperlancar proses belajar mandiri siswa SMA.menjadi salah satu kebutuhan pembelajaran saat ini terutama pada bidang matematika. Pada masa pandemi, pembelajaran matematika semakin mengalami penurunan minat dari siswa karena pembelajaran jarak jauh tanpa pengawasan guru. Berdasarkan pengamatan Pramudya, dkk (2017) mengatakan kebanyakan dari siswa lebih cenderung mengobrolkan topik tentang game dari pada pembelajaran di sekolah. Maka, dibutuhkan suatu media pembelajaran yang dapat menjawab permasalahan di atas. Setelah membaca jurnal atau sumber lain, maka akan dibuat suatu media pembelajaran berbasis RPG.

Pada tahap ini juga dilakukan wawancara kepada beberapa siswa kelas XI MIPA 1 SMA Negeri 6 Purworejo dengan kesimpulan dari wawancara tersebut siswa kurang minat dengan pembelajaran matematika terlebih lagi mereka harus belajar secara mandiri pada masa pandemi. Oleh karena itu siswa membutuhkan suatu media yang dapat memenuhi kebutuhan belajar mereka.

\section{Desain}

Desain Baret Argeo menjadi salah satu komponen penting karena harus dirancang secara menarik agar dapat meningkatkan minat belajar siswa. Pada tahap ini terdiri dari beberapa kegiatan antara lain:

a. Pembelian software.

Baret Argeo dibuat menggunakan software bernama RPG Maker MV yang dapat dibeli di Steam (penyedia game PC) seharga Rp. 111.860.

b. Pembuatan maps.

Maps ini terdiri dari 10 maps yang berbeda antara lain (istana, desa, pusat irigasi, dan lain-lain). Desain maps juga disesuaikan 


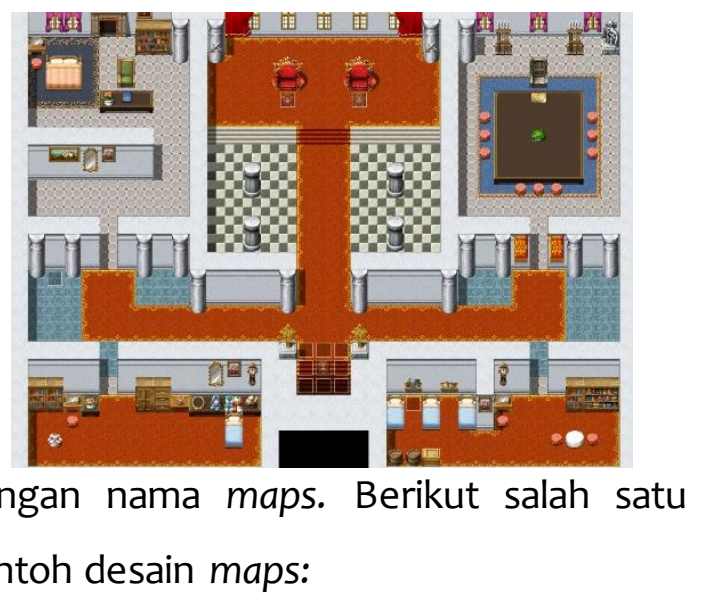

\section{Gambar 2. Map Istana pada Baret Argeo}

c. Pembuatan alur cerita.

Alur cerita pada Baret Argeo adalah seorang raja sedang mencari patih kerajaan. Pemain berlaku sebagai Fawazz (calon patih) untuk dapat menjawab dan mencermati materi sehingga dapat menjadi patih.

d. Pembuatan soal \& materi .

Materi, motivasi, dan soal pada Baret Argeo tentang barisan dan deret aritmatika dan geometri sesuai dengan kurikulum kelas XI MIPA. Contoh materi sebagai berikut:

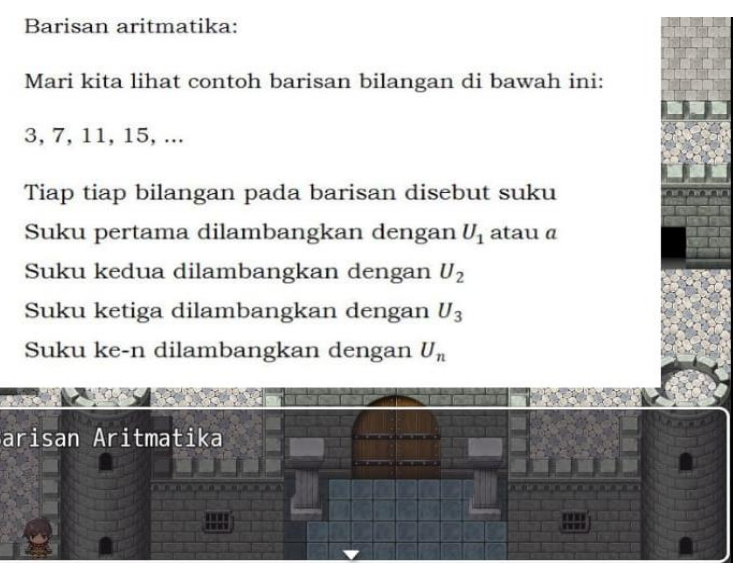

\section{Gambar 3. Contoh materi pada Baret Argeo}

Berikut contoh soal dan pada Baret Argeo:

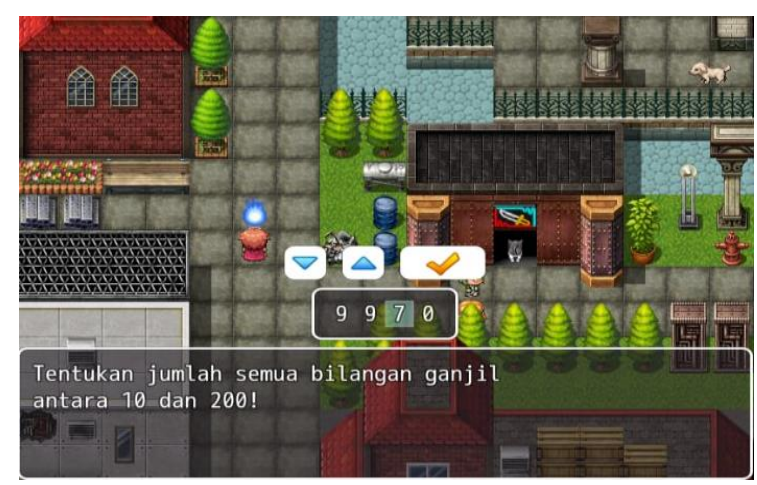

Gambar 4. Contoh Soal pada Baret Argeo

e. Penginstallan game di android.

Baret Argeo dapat dimainkan di android dan dimainkan secara offline dengan ukuran file tidak terlalu besar yaitu $87 \mathrm{Mb}$. Penginstallan dapat melalui hp siswa masing-masing dengan mudah. File dapat dikirim melalui Whatsapp, gmail, google classroom, dan lain-lain.

\section{Pengembangan}

Media ini selanjutnya dikembangkan melalui validasi media dan validasi materi.

a. Validasi Media

Validasi ini bertujuan mengembangkan media agar dapat dipakai di kelas subjek dilihat dari aspek media. Ada beberapa aspek yang dinilai. Validasi ahli media dilakukan oleh dua validator. 
Hasil validasi sebagai berikut:

Tabel 3. Hasil Validasi Media Baret Argeo

\begin{tabular}{llc}
\hline No & \multicolumn{1}{c}{ Aspek } & $\begin{array}{c}\text { Rata-rata tiap } \\
\text { aspek }\end{array}$ \\
\hline 1. & $\begin{array}{l}\text { Komunikasi } \\
\text { Visual }\end{array}$ & 4,43 \\
\hline 2. & $\begin{array}{l}\text { Perangkat } \\
\text { Lunak }\end{array}$ & 4,36 \\
\hline 3. & Kualitas Teknis & 4,58 \\
\hline & Rata-rata total & 4,46 \\
\hline
\end{tabular}

Dilakukan perhitungan dari hasil validasi media sesuai dengan tabel di atas. Perhitungan rata-rata setiap butir pernyataan dari total 15 butir pernyataan dengan skala 5. Lalu dilakukan perhitungan rata-rata setiap aspek dengan hasil rata-rata 4,43 untuk aspek komunikasi visual. Pada aspek perangkat lunak didapatkan rata-rata 4,36. Pada aspek kualitas teknis didapat rata-rata 4,58. Dari ketiga aspek di atas, dihitung lagi rata-rata total (RTV) Baret Argeo yaitu 4,46. Berdasarkan skala Likert, RTV lebih dari 4, maka rataan total validasi media dikategorikan sangat valid.

b. Validasi Materi

Validasi ini untuk menilai media ditinjau dari materi, soal, dan motivasi media agar sesuai dengan sasaran yaitu kelas XI MIPA. Validasi dilakukan oleh dua ahli materi. Berikut hasil validasi materi:
Tabel 4. Hasil Validasi Materi Baret Argeo

\begin{tabular}{llc}
\hline No & \multicolumn{1}{c}{ Aspek } & $\begin{array}{c}\text { Rata-rata tiap } \\
\text { aspek }\end{array}$ \\
\hline 1. & $\begin{array}{l}\text { Kesesuaian } \\
\text { Kurikulum }\end{array}$ & 4 \\
\hline 2. & Penyajian Materi & 3,79 \\
\hline 3. & Minat Belajar & 4 \\
\hline & Rata-rata total & 3,93 \\
\hline
\end{tabular}

Validasi materi sebagai konten di dalam Baret Argeo yang berimplikasi pada pembelajaran termasuk minat belajar. Hampir sama dengan validasi media, validasi materi terdiri dari 15 butir pernyataan dan terbagi menjadi tiga aspek. Pada aspek kesesuaian dengan kurikulum memberikan rata-rata 4. Aspek penyajian materi pada Baret Argeo dengan rata-rata 3,79 dan aspek minat belajar memberikan rata-rata 4. Rataan total validasi materi yaitu 3,93 dari perhitungan tiga aspek di atas. Berdasarkan skala Likert, RTV materi berada di antara 3 hingga 4 maka dapat dikategorikan valid.

\section{Implementasi}

Pada tahap ini dilakukan uji coba media Baret Argeo kepada subjek penelitian yang dibandingkan dengan buku LKS. Berikut beberapa hasil analisis dari uji coba media Baret Argeo.

1. Uji Kepraktisan

Pada uji kepraktisan dilakukan penyebaran angket kepada 18 siswa yang 
menggunakan Baret Argeo dan mendapatkan hasil sebagai berikut:

Tabel 5. Hasil Uji Kepraktisan Baret Argeo

\begin{tabular}{clc}
\hline No & \multicolumn{1}{c}{ Aspek } & $\begin{array}{c}\text { Rata-rata } \\
\text { tiap aspek }\end{array}$ \\
\hline 1. & Kualitas Teknis & 4,01 \\
\hline 2. & Kejelasan Unsur Game & 4,01 \\
\hline 3. & Kualitas isi dan tujuan & 4,07 \\
\hline & Rata-rata total & 4,03 \\
\hline
\end{tabular}

Dari hasil uji kepraktisan di atas diperoleh hasil bahwa pada aspek kualitas teknis dengan rata-rata 4,01, sedangkan pada kejelasan unsu game juga 4,01, dan pada aspek kualitas isi dan tujuan dengan hasil kepraktisan 4,07. Berdasarkan RTP yang dihasilkan 4,03 maka media Baret Argeo sangat praktis untuk digunakan.

2. Uji Normalitas

Uji normalitas sebagai prasyarat apakah data sudah normal atau belum. Data yan digunakan adalah angket respon siswa setelah menggunakan Baret Argeo atau buku LKS. Berikut hasil analisis uji normalitas:

a. Normalitas Baret Argeo

Tabel 6. Hasil Uj Normalitas Baret

\begin{tabular}{ll}
\multicolumn{2}{c}{ Argeo } \\
\hline $\mathbf{N}$ & $\mathbf{1 8}$ \\
\hline Rata-rata & 78,96 \\
\hline $\begin{array}{l}\text { Standar } \\
\text { deviasi }\end{array}$ & 10,01 \\
\hline D hitung & 0,125 \\
\hline D tabel & 0,318 \\
\hline
\end{tabular}

Dari tabel di atas dapat diketahui bahwa $D_{\text {hitung }}<D_{\text {tabel }}$ yaitu $0,125<0,318$ maka $H_{0}$ diterima atau dengan kata lain hasil angket penggunaan Baret Argeo berdistribusi normal.

b. Normalitas LKS

Tabel 7. Hasil Uj Normalitas Baret Argeo

\begin{tabular}{ll}
\hline $\mathbf{N}$ & $\mathbf{1 8}$ \\
\hline Rata-rata & 66,07 \\
\hline $\begin{array}{l}\text { Standar } \\
\text { deviasi }\end{array}$ & 6,95 \\
\hline D hitung & 0,154 \\
\hline D tabel & 0,318 \\
\hline
\end{tabular}

Dari tabel di atas dapat diketahui bahwa $D_{\text {hitung }}<D_{\text {tabel }}$ yaitu $0,154<0,318$ maka $H_{0}$ diterima atau dengan kata lain hasil angket penggunaan LKS berdistribusi normal.

3. Uji Homogenitas

Uji homogenitas dilakukan untuk mengetahui apakah data angket Baret Argeo dan LKS berasal dari variansi yang sama. Berikut hasil analisis:

Tabel 8. Hasil Uj Normalitas Baret Argeo

\begin{tabular}{lcc}
\hline \multicolumn{1}{c}{ Hasil } & Baret Argeo & LKS \\
\hline Rata-rata & 78,96 & 66,07 \\
\hline Variansi & 100,09 & 48,36 \\
\hline Df & 17 & 17 \\
\hline F hitung & \multicolumn{2}{c}{2,0697} \\
\hline F tabel & \multicolumn{2}{c}{2,2719} \\
\hline
\end{tabular}

Dari hasil di atas dapat diketahui bahwa $F_{\text {hitung }}<F_{\text {tabel }}$ yaitu $2,0697<2,2719$ maka $H_{0}$ diterima atau dengan kata lain 
data hasil angket penggunaan LKS berasal dari variansi yang sama (homogen).

4. Uji t

Tabel 9. Hasil Uji t

\begin{tabular}{lcc}
\multicolumn{1}{c}{ Hasil } & $\begin{array}{c}\text { Baret } \\
\text { Argeo }\end{array}$ & LKS \\
\hline Rata-rata & 78,96 & 66,07 \\
\hline Variansi & 100,09 & 48,36 \\
\hline Df & \multicolumn{2}{c}{34} \\
\hline t hitung & \multicolumn{2}{c}{4,4881} \\
\hline t tabel & \multicolumn{2}{c}{2,0322} \\
\hline
\end{tabular}

Dari data di atas dapat diketahui $t_{\text {hitung }}>t_{\text {tabel }} \quad$ yaitu $\quad 4,4881>$ 2,0322 maka $H_{0}$ ditolak atau dapat dikatakan minat belajar siswa yang menggunakan Baret Argeo lebih baik dari siswa yang menggunakan LKS.

5. Analisis Lembar Observasi

Lembar observasi sebagai pendukung data pada saat penelitian diamati selama penelitian secara online melalui grup whatsapp sesuai dengan grupnya.

Tabel 10. Hasil Observasi

\begin{tabular}{|c|c|c|c|}
\hline \multirow[t]{2}{*}{ No } & \multirow[t]{2}{*}{ Aspek } & \multicolumn{2}{|c|}{ Dilakukan } \\
\hline & & $\mathrm{Ya}$ & Tidak \\
\hline 1. & Antusias & $\sqrt{ }$ & \\
\hline 2. & Pemahaman & $\sqrt{ }$ & \\
\hline 3. & Minat media & $\sqrt{ }$ & \\
\hline 4. & Disiplin & $\sqrt{ }$ & \\
\hline 5. & Daya saing & $\sqrt{ }$ & \\
\hline 6. & Tanggung jawab & $\sqrt{ }$ & \\
\hline 7. & Kejujuran & $\sqrt{ }$ & \\
\hline 8. & Semangat & $\sqrt{ }$ & \\
\hline 9. & Esensi & $\sqrt{ }$ & \\
\hline 10. & Pemahaman materi & $\sqrt{ }$ & \\
\hline
\end{tabular}

Dari tabel di atas dapat diketahui bahwa semua aspek kegiatan dilakukan pada saat penelitian sehingga beimplikasi pada minat belajar siswa yang tinggi pada Baret Argeo.

\section{Pembahasan}

Proses pengembangan diawali dengan analisis kebutuhan suatu media terutama pada pembelajaran matematika. Kebutuhan media ini juga didasari karena pada masa pandemi yang merubah tatanan pendidikan sehingga siswa harus belajar secara mandiri. Minat belajar matematika yang rendah apalagi harus belajar secara mandiri harus dibutuhkan suatu media yang dapat memenuhi kebutuhan belajar matematika agar minat belajar tinggi. Siswa cenderung suka bermain game, oleh karena itu dibuat suatu media berjenis game yang dapat menumbuhkan minat belajar matematika di tengah pembelajaran jarak jauh bernama Baret Argeo. Materi pada Baret Argeo yaitu barisan dan deret aritmatika dan geometri dipilih karena cenderung tidak memuat suatu rumus yang banyak akan tetapi banyak siswa yang belum paham mengenai materi tersebut.

Baret Argeo adalah media belajar berbentuk game RPG dimana siswa dapat memainkan Baret Argeo di android sehingga dapat dimainkan di mana saja dan kapan saja sambil belajar memerankan suatu tokoh. Baret Argeo didesain sedemikian rupa sehingga mudah dimainkan. Desain tersebut antara lain pembuatan map sebagai tempat 
bermain, membuat karakter, membuat jalan cerita yaitu seorang raja sedang mencari patih kerajaan. Pemain Baret Argeo berlaku sebagai calon patih dan harus menyelesaikan dan memahami semua soal dan materi yang ada. Pembuatan narasi juga dilakukan agar siswa mempunyai petunjuk yang jelas dalam bermain. Unsur-unsur lain seperti menambahkan item-item seperti pohon, pedang, dan tuas juga dilakukan dalam tahap mendesain ini. Quest pada Baret Argeo adalah suatu program untuk misi yaitu dalam berpindah tempat untuk menyelesaikan game, siswa harus dapat menjawab semua soal yang ada pada tempat tersebut. Unsur quest antara lain pembuatan variabel dan mengolah variabel tersebut dengan programprogram dan ditambahkan plug-in sederhana.

Memasukkan materi barisan dan deret juga dilakukan sesuai dengan kurikulum yang berlaku. Selain itu terdapat motivasi sebagai pembelajaran di dalam baret Argeo. Kemudian diberikan contoh yang realistik agar siswa lebih dapat memahami pembelajaran dan juga pembahasan pada setiap soal. Total soal yang ada pada Baret Argeo adalah 20 butir soal dengan masingmasing 5 soal di setiap subbab.

Tahap pengembangan dimulai dengan mengekspor Baret Argeo dari laptop ke android. Selanjutnya dilakukan validasi media dan materi. Pada validasi media oleh dua validator didapatkan kategori sangat valid dengan nilai 4,46. Dalam validasi media juga diperbaiki aspek pada Baret Argeo melalui revisi masukan dari validator yaitu perbaikan navigasi dan ukuran file. Validasi materi dilakukan untuk menguji ketepatan materi yang ada pada Baret Argeo. Validasi materi dilakukan juga oleh dua validator dengan nilai 3,93 atau valid. Artinya materi pada Baret Argeo sudah tepat sesuai dengan sasaran dan kurikulum yang ada. Perbaikan revisi pada validasi materi antara lain perbaikan contoh masalah konstektual yang lebih realistik dan penambahan pembahasan pada butir soal.

Tahap implementasi penelitian ini awalnya dilakukan ujicoba kelas kecil oleh dua siswa kelas XI MIPA diluar sampel untuk mengetahui respon pertama siswa. Selanjutnya dilakukan ujicoba kelas besar di kelas XI MIPA 1 SMA Negeri 6 Purworejo dengan pembagian dua grup yaitu grup Baret Argeo berjumlah 18 siswa dan grup LKS berjumlah 18 siswa sebagai pembandingnya. Pada penelitian ini, masin-masing grup mengujicobakan setiap media sesuai dengan grupnya lalu menilai atau memberikan respon terhadap media tersebut dengan mengisi angket.

Angket pertama yaitu angket uji kepraktisan yang diisi oleh 18 siswa grup Baret Argeo untuk mengetahui apakah Baret Argeo praktis untuk digunakan. Hasil uji 
kepraktisan yaitu dengan nilai 4,03 atau dapat dikategorikan sangat praktis. Kemudian masin-masing grup mmberikan respon terhadap media Baret Argeo dan LKS dan kemudian dibandingkan. Sebelum pada hasil akhir, data angket diolah normalitas dan homogenitasnya. Dengan metode Kolmogorov-Smirnov untuk normalitas memberikan kesimpulan data angket Baret Argeo dan LKS berdistribusi normal. Sedangkan uji homogenitas dengan metode uji $\mathrm{F}$ menghasilkan kesimpulan data Baret Argeo dan LKS berasal dari variansi yang sama atau homogen. Kemudian minat belajar menggunakan Baret Argeo dan LKS dibandingkan menggunakan uji $t$ dengan kesimpulan minat belajar siswa yang menggunakan Baret Argeo lebih tinggi daripada siswa yang menggunakan LKS.

Penelitian ini dibandingankan dengan penelitian terdahulu yang dilakukan oleh Eldiana \& Muliawati dengan pokok penelitian pengembangan game COC RPG Make MV sebagai media pembelajaran pada materi KPK. Persamaan kedua penelitian antara lain: bidang matematika, model pengembangan ADDIE, jenis game yang digunakan yaitu game dan menggunakan software RPG Maker MV. Beberapa perbedaan kedua penelitian tersebut antara lain materi yang digunakan yaitu barisan deret dan KPK. Selain itu nama yang digunakan untuk media juga berbeda yaitu Baret Argeo (Baris Deret
Aritmatika dan Geometri) dan COC (Competiton of Mathematic. Jenjang yang digunakan juga berbeda yaitu untuk siswa SMA kelas XI MIPA dan siswa SMP. Perangkat yang digunakan untuk pengoperasian antara android dan laptop. Pada penelitian Baret Argeo dengan hasil validasi media 4,46 dan validasi materi 3,93. Sedangkan pada penelitian COC dengan validasi media 4,14 dan validasi materi 3,96. Kepraktisan kedua media yaitu 4,03 untuk Baret Argeo dan 4,1 untuk COC. Keefektifan media pada Baret Argeo bermuara pada minat belajar yang lebih baik daripada media konvensional. Sedangkan media COC bermuara untuk mengetahui hasil belajar yang belum diungkapkan.

\section{SIMPULAN DAN SARAN}

\section{Simpulan}

Media Baret Argeo menjadi media berbasis game teknologi yang dapat dimainkan melalui android sebagai media belajar di tengah pandemi untuk meningkatkan minat belajar matematika siswa.

\section{Saran}

Media Baret Argeo ini dikembangkan untuk meningkatkan minat belajar siswa. Semoga nantinya media ini dapat dikembangkan secara lebih luas lagi. 


\section{REFERENSI}

Fadillah, A. (2016). Analisis Minat Belajar dan Bakat terhadap Hasil Belajar Matematika Siswa. Mathline Jurnal Matematika dan Pendidikan Matematika, 1 (2), 113-122.

Febriyanti, C. \& Seruni. (2016). Peran Minat dan Interaksi Siswa dengan Guru dalam Meningkatkan Hasil Belajar Matematika. Formatif: Jurnal Ilmiah Pendidikan MIPA, 4(3), 245-254.

Fuqoha, A. A. N. (2015). Pengembangan Game RPG (Role Play Game) sebagai Media Pembelajaran Berbasis Guided Inquiry pada Materi Segiempat dan Segitiga untuk Siswa SMP Kelas VII. Diakses pada tanggal 29 September 2020 dari www.semanticscholar.org/paper/

Masjudin. (2016). Pembelajaran Kooperatif Investigatif untuk Meningkatkan Pemahaman Siswa Materi Barisan Dan Deret. Jurnal Edukasi Matematika dan Sains (JEMS), 4 (2), 76-84.

Munir. (2009). Pembelajaran Jarak Jauh Berbasis Teknologi Informasi dan Kominukasi. Bandung: Alfabeta.
Nazir, M. (2013). Metode Penelitian. Bogor: Ghalia Indonesia.

Nurtasari, H.R., \& Manoy, J.T. (2016). Pengembangan Lembar Kegiatan Siswa (LKS) dengan Media Tangram pada Pembelajaran Matematika Materi Jajar Genjang dan Belah Ketupat. MATHedunesia: Jurnal Ilmiah Pendidikan Matematika, 3 (5).

Pramudya, S. A., Noto, M. S., Syaefullah, D. (2017). Game Edukasi RPG Matematika. Jurnal EduMa: Mathematics Education Learning and Teaching. 6 (1).

Siagian, R. E. F. (2015). Pengaruh Minat dan Kebiasaan Belajar Siswa Terhadap Prestasi Belajar Matematika. Jurnal Formatif: Jurnal Ilmiah Pendidikan MIPA, 2 (2), 122-131.

Suparni \& Handayani, S. (2018). Pengaruh Bermain Game Online terhadap Minat Belajar Siswa. Jurnal Speed: Sentra Penelitian Engineering dan Edukasi, 10 (2), 1-6. 